\title{
Aerobic Exercise Training Increases Muscle Water Content in Obese Middle-Age Men
}

\author{
AQ1 RICARDO MORA-RODRÍGUEZ ${ }^{1}$, ALICIA SANCHEZ-RONCERO ${ }^{1}$, VALENTIN EMILIO FERNÁNDEZ-ELÍAS ${ }^{1}$, \\ AMELIA GUADALUPE-GRAU ${ }^{1}$, JUAN FERNANDO ORTEGA ${ }^{1}$, FLEMING DELA ${ }^{2}$, and JORN WULFF HELGE ${ }^{2}$ \\ ${ }^{1}$ Exercise Physiology Laboratory at Toledo, University of Castilla-La Mancha, Toledo, SPAIN; and ${ }^{2}$ Xlab, Center for Healthy \\ Aging, Department of Biomedical Sciences, Faculty of Health Sciences, University of Copenhagen, Copenhagen, DENMARK
}

\begin{abstract}
MORA-RODRÍGUEZ, R. C., A. SANCHEZ-RONCERO, V. E. FERNÁNDEZ-ELÍAS, A. GUADALUPE-GRAU, J. F. ORTEGA, F. DELA, and J. W. HELGE. Aerobic Exercise Training Increases Muscle Water Content in Obese Middle-Age Men. Med. Sci. Sports Exerc., Vol. 48, No. 5, pp. 00-00, 2016. Purpose: The objective of this study is to determine whether muscle water content $\left(\mathrm{H}_{2} \mathrm{O}_{\text {muscle }}\right)$ expands with training in deconditioned middle-age men and the effects of this expansion in other muscle metabolites. Methods: Eighteen obese $\left(\mathrm{BMI}=33 \pm 3 \mathrm{~kg} \cdot \mathrm{m}^{-2}\right)$ untrained $\left(\dot{\mathrm{VO}}_{2 \text { peak }}=29 \pm 7 \mathrm{~mL}^{-1} \cdot \mathrm{kg}^{-1} \cdot \mathrm{min}^{-1}\right)$ metabolic syndrome men completed a 4-month aerobic cycling training program. Vastus lateralis muscle biopsies were collected before and $72 \mathrm{~h}$ after the completion of the last training bout. Water content, total protein, glycogen concentration, and citrate synthase activity were measured in biopsy tissue. Body composition was assessed using dual-energy X-ray absorptiometry, and cardiometabolic fitness was measured during an incremental cycling test. Results: Body weight and fat mass were reduced $-1.9 \%$ and $-5.4 \%$, respectively $(P<0.05)$, whereas leg fat free mass increased with training $(1.8 \%, P=0.023)$. Cardiorespiratory fitness (i.e., $\dot{\mathrm{VO}}_{2 \text { peak }}$ ), exercise maximal fat oxidation (i.e., $\mathrm{FO}_{\max }$ ), and maximal cycling power (i.e., $\left.W_{\max }\right)$ improved with training $(11 \%, 33 \%$, and $10 \%$, respectively; $P<0.05)$. After 4 months of training, $\mathrm{H}_{2} \mathrm{O}_{\text {muscle }}$ increased from $783 \pm 18$ to $799 \pm 24 \mathrm{~g} \cdot \mathrm{kg}^{-1}$ wet weight (ww) $(2 \%, P=0.011)$, whereas muscle protein concentration decreased $11 \%$ ( $145 \pm 15$ to $\left.129 \pm 13 \mathrm{~g} \cdot \mathrm{kg}^{-1} \mathrm{ww}, P=0.007\right)$. Citrate synthase activity (proxy for mitochondrial density) increased by $31 \%(17 \pm 5$ to $\left.22 \pm 5 \mathrm{mmol} \cdot \mathrm{min}^{-1} \cdot \mathrm{kg}^{-1} \mathrm{ww}, P=0.024\right)$. Muscle glycogen concentration increased by $14 \%\left(22 \pm 7\right.$ to $\left.25 \pm 7 \mathrm{~g} \cdot \mathrm{kg}^{-1} \mathrm{ww}\right)$ although without reaching statistical significance when expressed as per kilogram of wet weight $(P=0.15)$. Conclusions: Our findings suggest that aerobic cycling training increases quadriceps muscle water although reduces muscle protein concentration in obese metabolic syndrome men. Reduced protein concentration coexists with increased leg lean mass suggestive of a water dilution effect that however does impair increased cycling leg power with training. Key Words: EXERCISE TRAINING, MUSCLE WATER CONTENT, MUSCLE HYPERTROPHY, AGING
\end{abstract}

$\mathrm{M}$ ore than 50 yr ago, Pace and Rathbun (25) first proposed that total body water (TBW) is a constant fraction of fat free mass (FFM) based on experiments in guinea pigs. This constant value (i.e., TBW/FFM = 0.73 ) later confirmed in humans cadavers (37) allows the calculation of body composition when using dual x-ray absorptiometry and hydrodensitometry (28). It is also the foundation for calculating body fat from measures of TBW by dilution methods (fat = body mass - TBW/0.73) (36). The use of this constant implies a fixed FFM-to-water content ratio (i.e., FFM hydration). More than half of FFM is skeletal muscle (31), and thus, this constant also assumes fixed skeletal muscle hydration. In fact, muscle water content reported

AQ2 Address for correspondence: Ricardo Mora-Rodriguez, Ph.D., University of Castilla-La Mancha, Avda. Carlos III, s/n, 45071, Toledo, SPAIN; E-mail: Ricardo.mora@uclm.es.

Submitted for publication September 2015.

Accepted for publication December 2015.

0195-9131/16/4805-0000/0

MEDICINE \& SCIENCE IN SPORTS \& EXERCISE $_{\circledast}$ Copyright $\left({ }^{\circ} 2015\right.$ by the American College of Sports Medicine

DOI: $10.1249 /$ MSS.0000000000000848 in resting healthy young subjects coincides across studies (i.e., $\sim 78 \% \pm 3 \%)(6-9,13,14,20,22,29,30)$.

The water-to-FFM constant originates from experiments where animals or human cadavers were thoroughly homogenized, fat was extracted, and water content was determined by weighing homogenate aliquots before and after drying by evaporation or sublimation (i.e., freeze-drying). Similar processing of a muscle biopsy sample allows the measurement of muscle water content in vivo. Using this technique, it has been shown that congestive heart failure patients increase leg muscle water content in comparison with age-matched healthy controls (2) likely because of reduced venous return provoking edema. In healthy men, short intense exercise increases muscle water content (30) likely because of increased transcapillary pressure. Conversely, submaximal prolonged exercise in a hot environment results in whole body dehydration and losses of muscle water content (6). We have recently shown that whole body dehydration by $4.2 \%$ reduces muscle water content when $1 \mathrm{~h}$ of recovery is allowed to reequilibrate among body fluids spaces (20).

Although it is clear that muscle water content can transitorily change in response to a bout of exercise, the effects of chronic exercise training on muscle water content are not well 
defined. To our knowledge, only four studies in humans report the effects of training on muscle water changes. All of them report water content as a secondary finding to the study of muscle hypertrophy. One study uses nuclear magnetic resonance to estimate leg water changes after leg extension training in young subjects finding no effects (17). Three of them use direct measurement of water content in leg muscle biopsies $(13,14,29)$. One is a cross-sectional comparison between competitive and recreational runners and thus subjected to the effects of different diets, muscle fiber composition, genetics, and hormonal milieu between groups (29). The two remaining studies follow a repeated-measures design in the same group of subjects before and after $12 \mathrm{wk}$ of cycle ergometer training. However, although the first study conducted in old women finds increases in muscle water content with training (10), the subsequent study conducted in old and young men does not (11).

Despite the utmost relevance of water for muscle energetics during and after exercise $(9,10)$, the effects of chronic training on muscle water content remain unclear. A few aerobic training exercise sessions expand intravascular water (i.e., plasma volume expansion) allowing better cardiac function, cutaneous blood flow, and sweat gland fluid supply (4). It is however unclear if water within muscles is also expanded with aerobic training to improve muscle energetics and/or contractile function. To study muscle water changes in a sedentary population initially seems pertinent to unveil if muscle conditioning includes muscle water expansion and how does it relate to other known muscle training adaptations (e.g., increase in mitochondrial density or glycogen content). We hypothesized that a health-oriented fitness-training program using aerobic interval exercise will increase muscle water content in initially sedentary metabolic syndrome men. We will relate the changes in muscle water content to muscle variables known to change with training (mitochondrial and glycogen content) in an attempt to establish possible links.

\section{METHODS}

Participants. Eighteen obese men between 34 and $64 \mathrm{yr}$ old (mean, $54 \pm 8$ yr old) completed the study. Participants were enrolled based on fulfilling the $\geq 3$ METs criteria as per harmonized definition (1) using population Europid waist circumference cut-points. Exclusion criteria included cardiovascular or renal disease, peripheral vascular disease, and any disease associated with exercise intolerance. Body weight stability in the last 6 months (i.e., changes below 1\% of initial body weight) was also a requirement. Participants reported not being engaged in regular physical activity beyond walking less than $30 \mathrm{~min} \cdot \mathrm{d}^{-1}$ in the past 6 months. The local hospital's research ethics committee approved the study procedures and the informed consent documents. Subjects were informed of the purpose and risks involved in the study before signing the written consent. The study fulfilled the latest version of the Declaration of Helsinki.

Exercise training and dietary records. Subjects underwent supervised aerobic interval training (AIT) with a frequency of three times per week for 4 months. Training consisted of pedaling for $10 \mathrm{~min}$ as a warm-up at $70 \%$ $\mathrm{HR}_{\max }$ followed by $4 \times 4$-min intervals at $90 \%$ of $\mathrm{HR}_{\max }$ interspersed with 3-min active recovery at $70 \% \mathrm{HR}_{\max }$ and a 5-min cool-down period for a total of $43 \mathrm{~min}$. Exercise intensity was increased as training adaptations developed to maintain the target HR (Accurex coded; Polar, Finland). Participants were required to attend at least $85 \%$ of all the exercise sessions. Subjects were instructed to maintain their dietary patterns during the duration of the study. A 3-d dietary $\log$ was collected monthly and analyzed for caloric intake and macronutrient composition.

Cardiorespiratory and metabolic fitness assessment. Before and after 4 months of training, we tested all subjects for weight, waist circumference, exercise maximal fat oxidation $\left(\mathrm{FO}_{\text {max }}\right)$, peak oxygen consumption $\left(\dot{\mathrm{VO}}_{2 \text { peak }}\right)$, and body composition. All tests were scheduled before and at least $72 \mathrm{~h}$ after the last exercise training session to avoid measuring the acute effects of the last exercise bout rather than the chronic effects of the exercise training program. In testing days, subjects arrived at the laboratory after an overnight fast. Upon arrival, subjects voided and their body weight was assessed (Hawk, Mettler Toledo). Urine was analyzed for specific gravity (Usg, Uricon-NE; Atago, Japan) to ensure that subjects were euhydrated (Usg < 1.015). Subjects rested in a stretcher for $20 \mathrm{~min}$ while the resting ECG was being examined (Cosmed T12, Italy). Then, exercise testing started in an electromagnetically braked cycle ergometer (Cardiotest 100; Seca, Germany) with three to eight submaximal 4-min stages to assess maximal fat oxidation $\left(\mathrm{FO}_{\max }\right)$. During the $\mathrm{FO}_{\max }$ test, oxygen consumption and carbon dioxide production were analyzed in a breath-by-breath mode (Quark b2, Cosmed). The test was discontinued when the RER exceeded 1 . The last minute of each stage was averaged to calculate the nonprotein respiratory quotient and fat oxidation rate (11). Next, subjects recovered for $40 \mathrm{~min}$ while $250 \mathrm{~mL}$ of juice was being ingested $(125 \mathrm{kcal})$. Then, a graded exercise test (GXT) was conducted to volitional fatigue to determine the subject's peak aerobic power $\left(\dot{\mathrm{V}}_{2 \text { peak }}\right)$. After a 5 -min warm-up at $100 \mathrm{~W}$, participants began cycling at $125 \mathrm{~W}$ with increments of $25 \mathrm{~W}$ each minute. Gas exchange data were collected using an automated breath-by-breath system and averaged every $15 \mathrm{~s}$. A physician visually inspected the ECG tracing during the GXT.

Body composition and biopsy tissue collection. Before the above-described test, subjects arrived after an overnight fast before and after training for body composition assessment and muscle biopsy collection. Percent body fat and right leg lean soft tissue mass were determined by dual-energy X-ray absorptiometry (DXA Hologic Serie Discovery Wi QDR; Hologic, Bedford, MA). Muscle biopsies were obtained before and at least $3 \mathrm{~d}$ after training from the vastus lateralis using a suction-modified Bergstrom technique (33). Skin was prepared with povidone-iodine (Betadine; MEDA, Paris, France), followed by injection of $2 \%$ lidocaine without epinephrine (Braun 2\%; Braun Medical, Spain). Then, the skin and underlying 
tissues were surgically opened (scalpel blade number 10; Braun, Germany) and muscle tissue was obtained using a 4-mm internal diameter Bergstrom biopsy needle. Upon collection, muscle samples were immediately cleaned of connective tissue, divided into two pieces, and rapidly frozen in liquid nitrogen for subsequent analysis of water and metabolite contents. The incision was closed using adheAQ3 sive strips (Steri-Strip ${ }^{\mathrm{TM}}, 3 \mathrm{M}$ ) covered with an adhesive dressing pad (Tegaderm $\left.{ }^{\mathrm{TM}}+\mathrm{Pad}, 3 \mathrm{M}\right)$ and compressive dressing (IcoVenda; Novico Medica, Spain).

Muscle water content measurement. All the samples from a given subject were analyzed in the same assay batch. Frozen samples were weighed on an electronic balance with a sensitivity of $0.1 \mu \mathrm{g}$ (XB220A; Precisa, Switzerland). Elapsed time from sample removal from the freezer until weighing was recorded to permit correction for tissue water evaporation. Samples were freeze-dried in a thermoelectric freeze dryer (Cryodos-50; Telstar, Spain) for $6 \mathrm{~h}$ at $-50^{\circ} \mathrm{C}$ and at a vacuum of $10^{-2}$ Torr. In brief, this apparatus freezes the liquid in the sample to $-50^{\circ} \mathrm{C}$ to then sublimate it with a potent vacuum pump at a high flux rate $\left(83 \mathrm{~L} \cdot \mathrm{min}^{-1}\right)$. Samples were then reweighed in the same precision scale to measure water content. Pilot data in our laboratory in fresh pig leg muscle indicated that $\mathrm{H}_{2} \mathrm{O}_{\text {muscle }}$ measurement was

AQ4 highly reproducible (i.e., $6 \% \mathrm{CV}$ ). Data in one subject that underwent 10 resting biopsies within 8 wk in a euhydrated state (Usg $<1.020$ and body weight $\pm 0.25 \mathrm{~kg}$ ) confirmed the high reproducibility of this technique in our laboratory in human muscle (i.e., $5 \% \mathrm{CV}$ ).

Muscle metabolites analysis. Glycogen concentration was determined from the measurement of glucose after acid hydrolysis analysis (26). Briefly, muscle samples ( $20 \mathrm{mg})$ were homogenized using a glass-on-glass system on ice with deionized water. Then, samples were hydrolyzed in $2 \mathrm{~N}$ hydrochloric acid and heated for $2 \mathrm{~h}$ at $100^{\circ} \mathrm{C}$ (Tembloc; JP Selecta, Spain). Finally, samples were neutralized to $\mathrm{pH}$ 6.5-7.5 with $1 \mathrm{~N}$ sodium hydroxide, and glucose concentration was analyzed by colorimetric assay (enzymatic glucose reagent; Thermo Scientific, Waltham, MA). Muscle protein was assayed after tissue homogenization using a modified Lowry technique with bicinchoninic acid (16). Citrate synthase activity was measured from an approximately $10-\mathrm{mg}$ portion of muscle through the reduction of 5,5'-dithiobis(2nitrobenzoic acid) by the release of CoA-SH in the cleaving of acetyl-CoA (32).

Statistical analysis. Data are presented as mean \pm SD. Sample size was calculated based on muscle water increases in three pilot subjects undergoing a similar training program. Power test revealed that at least 10 subjects were needed to reach significance for a statistical power at $80 \%(\alpha=0.05)$ (4). Normally distributed data were analyzed using Student's two-tailed paired $t$-test (pre- to posttraining comparison). A Pearson product-moment correlation coefficient was used to establish linear correlations (dependence) between the changes with training in muscle variables and muscle water. Level of significance was set at $P<0.05$. Cohen's formula for effect size (ES) (4) was used, and the results were based on the following criteria: $>0.70$ large effect; $0.30-0.69$ moderate effect; $\leq 0.30$ small effect. Confidence intervals (95\%) are also presented. Data analysis was performed using SPSS software for windows (v.18, IBM).

\section{RESULTS}

The group was quite homogenous regarding body weight, BMI, and waist circumference (Table 1, pretraining column). T1 Although their initial cardiorespiratory fitness $\left(\mathrm{V}_{2 \text { peak }}\right.$, Table 1) had a coefficient of variation of $24 \%$, they were all largely untrained according to the normative values for their age and gender (38).

Cardiometabolic fitness and exercise capacity. $\dot{\mathrm{VO}}_{2 \text { peak }}$ increased significantly after 4 months of AIT by $3 \mathrm{~mL} \cdot \mathrm{kg}^{-1} \cdot \mathrm{min}^{-1}$ (95\% CI, $\left.5-2 \mathrm{~mL} \cdot \mathrm{kg}^{-1} \cdot \mathrm{min}^{-1} ; \mathrm{ES}=0.44 ; P=0.001\right)$. In turn, $\mathrm{FO}_{\max }$ increased by $0.08 \mathrm{~g} \cdot \mathrm{min}^{-1}$ (i.e., $33 \%$ ) after 4 months of training $\left(95 \% \mathrm{CI}, 0.12-0.04 \mathrm{~g} \cdot \mathrm{min}^{-1} ; \mathrm{ES}=0.78\right.$; $P=0.003)$. During the GXT, cycling power output increased by $23 \mathrm{~W}$ (i.e., $10 \%$ from $232 \pm 67$ to $255 \pm 75 \mathrm{~W}$; Table 1 ) at the end of the training program $(95 \% \mathrm{CI}, 32-14 \mathrm{~W}$; $\mathrm{ES}=0.32 ; P=0.001)$.

Anthropometry and body composition. Although subjects did not undergo a hypocaloric diet, body weight was reduced by $1.85 \mathrm{~kg}(1.9 \%$; from $95.2 \pm 9.7$ to $93.4 \pm$ $9.6 \mathrm{~kg}$ ) after 4 months of training ( $95 \% \mathrm{CI},-0.4$ to $-3.3 \mathrm{~kg}$; $\mathrm{ES}=0.19 ; P=0.022)$. Furthermore, macronutrient distribution in diet remained constant throughout the 4 months of the study, with $41 \% \pm 2 \%$ of energy intake from carbohydrates, $38 \% \pm 1 \%$ from fat ( $40 \%$ saturated), and $21 \% \pm$ $1 \%$ from protein. Because of the body weight losses, BMI was also reduced by a similar magnitude (from 33.4 to $32.7 \mathrm{~kg} \cdot \mathrm{m}^{-2} ; 95 \% \mathrm{CI},-0.2$ to $-1.3 \mathrm{~kg} \cdot \mathrm{m}^{-2}$; $\mathrm{ES}=0.30$; $P=0.013)$. Fat mass measured by DXA was also significantly reduced with training $(-1.7 \mathrm{~kg} ; 95 \% \mathrm{CI},-0.17$ to $-3.28 \mathrm{~kg} ; \mathrm{ES}=0.37 ; P=0.044$ ), whereas whole body FFM did not significantly change. However, sectional DXA analysis of the right leg revealed a significant increase of $1.8 \%$ in FFM $(0.2 \mathrm{~kg} ; 95 \% \mathrm{CI}, 0.31-0.05 \mathrm{~kg} ; \mathrm{ES}=0.10 ; P=0.023$; Table 1).

Muscle water content. Before exercise, vastus lateralis contained $363 \pm 36 \mathrm{~mL}$ of water per 100 -g dry weight (dw) muscle. After 4 months of exercise, muscle water content (i.e., $\mathrm{H}_{2} \mathrm{O}_{\text {muscle }}$ ) increased by $12 \%$ to $404 \pm 69 \mathrm{~mL}$ per 100 -g dw muscle $(P=0.019)$. When the changes in water were expressed

TABLE 1. Exercise and anthropometric changes with 4 months of AIT.

\begin{tabular}{lccrc}
\hline & Pretraining & Posttraining & $\%$ Change & $P$ value \\
\hline$\dot{V}_{2 \text { peak }}\left(\mathrm{mLO}_{2} \cdot \mathrm{kg}^{-1} \cdot \mathrm{min}^{-1}\right)$ & $28.8 \pm 7$ & $32.1 \pm 8$ & $11 \%$ & $0.001^{*}$ \\
$\mathrm{FO}_{\max }\left(\mathrm{g} \cdot \mathrm{min}^{-1}\right)$ & $0.24 \pm 0.09$ & $0.32 \pm 0.11$ & $33 \%$ & $0.003^{*}$ \\
Workload $_{\max }\left(W_{\max }\right)$ & $232 \pm 67$ & $255 \pm 75$ & $10 \%$ & $0.001^{*}$ \\
Body weight $(\mathrm{kg})$ & $95.21 \pm 10$ & $93.36 \pm 10$ & $-1.9 \%$ & $0.022^{*}$ \\
$\mathrm{BMI}\left(\mathrm{kg} \cdot \mathrm{cm}^{-2}\right)$ & $33.4 \pm 3$ & $32.7 \pm 2$ & $-2.2 \%$ & $0.013^{\star}$ \\
Waist circumference $(\mathrm{cm})$ & $109 \pm 5$ & $107 \pm 5$ & $-1.8 \%$ & $0.016^{*}$ \\
Fat mass $(\mathrm{kg})$ & $31.9 \pm 4.3$ & $30.1 \pm 5.1$ & $-5.4 \%$ & $0.044^{*}$ \\
FFM $(\mathrm{kg})$ & $59.9 \pm 9$ & $60.3 \pm 8$ & $0.5 \%$ & 0.477 \\
Right leg FFM $(\mathrm{kg})$ & $9.84 \pm 1.84$ & $10.02 \pm 1.85$ & $1.8 \%$ & $0.023^{*}$ \\
\hline
\end{tabular}

Data are mean \pm SD for 18 subjects. *Significantly different from pretraining. 
as per wet weight (i.e., physiological muscle condition), the increases in $\mathrm{H}_{2} \mathrm{O}_{\text {muscle }}$ were of $16 \mathrm{~g} \cdot \mathrm{kg}^{-1}$, increasing from $783 \pm 18$ to $799 \pm 24 \mathrm{~g} \cdot \mathrm{kg}^{-1} \mathrm{ww}(95 \% \mathrm{CI}, 27-5 \mathrm{~kg}$; $\mathrm{ES}=0.76 ; P=0.011 ;$ Fig. 1$)$

Muscle metabolites. Glycogen concentration increased by $19 \%$ as a result of training (546 \pm 146 to $650 \pm$ $158 \mathrm{mmol} \cdot \mathrm{kg}^{-1} \mathrm{dw}$ ) when expressed as per dry weight (95\% CI, 180-27 mmol $\mathrm{kg}^{-1} \mathrm{dw}$; ES $\left.=0.68 ; P=0.017\right)$. However, when glycogen concentrations were expressed as per wet weight, the increases were of $14 \%$ and did not reach statistical significance (from $22 \pm 7$ to $25 \pm 7 \mathrm{~g} \cdot \mathrm{kg}^{-1}$ ww; $95 \%$ $\mathrm{CI}, 7$ to $-1 \mathrm{~g} \cdot \mathrm{kg}^{-1} \mathrm{ww}$; $\mathrm{ES}=0.43 ; P=0.154$; Fig. 2). Total protein concentration was significantly reduced after 4 months of training by $11 \%$ from $145 \pm 15$ to $129 \pm 13 \mathrm{~g} \cdot \mathrm{kg}^{-1} \mathrm{ww}$ $\left(95 \% \mathrm{CI},-6\right.$ to $-26 \mathrm{~g} \cdot \mathrm{kg}^{-1} \mathrm{ww} ; \mathrm{ES}=1.17 ; P=0.007$; Fig. 2). Citrate synthase activity increased by $31 \%$ from $17 \pm 5$ to $22 \pm 5 \mathrm{mmol} \cdot \mathrm{min}^{-1} \cdot \mathrm{kg}^{-1} \mathrm{ww}(95 \% \mathrm{CI}$, 8-3 mmol. $\mathrm{min}^{-1} \cdot \mathrm{kg}^{-1}$ ww; $\mathrm{ES}=1.08 ; P=0.001$; Fig. 2).

Metabolic syndrome components. After $16 \mathrm{wk}$ of training, three out of the five components of metabolic syndrome significantly improved. Waist circumference (index of abdominal obesity) was reduced by $2 \%$ (i.e., $2 \mathrm{~cm}$ ), fasting blood glucose by $7 \%\left(0.5 \mathrm{mmol} \cdot \mathrm{L}^{-1}\right)$, and mean arterial pressure by $7 \%(8 \mathrm{~mm} \mathrm{Hg})$. However, blood triglyceride and HDL cholesterol concentrations did not improve with training.

Correlations of muscle tissue analysis. Pearson correlation coefficient analyses were performed in selected variables using wet weight as the physiological muscle conditions for expressing concentrations (glycogen and protein), content (water), and enzyme activity (citrate synthase $\left(\mathrm{CS}_{\text {activity }}\right)$ ). The increase in $\mathrm{H}_{2} \mathrm{O}_{\text {muscle }}$ was associated with reductions in protein, muscle glycogen concentration, and citrate synthase activity (Table 2). Conversely, the changes in protein concentration were positively associated with the changes in $\mathrm{CS}_{\text {activity }}$.

\section{DISCUSSION}

We trained 18 obese metabolic syndrome patients for 4 months (i.e., 48 sessions) using an intense AIT program (34) and obtained the typical cardiometabolic and body

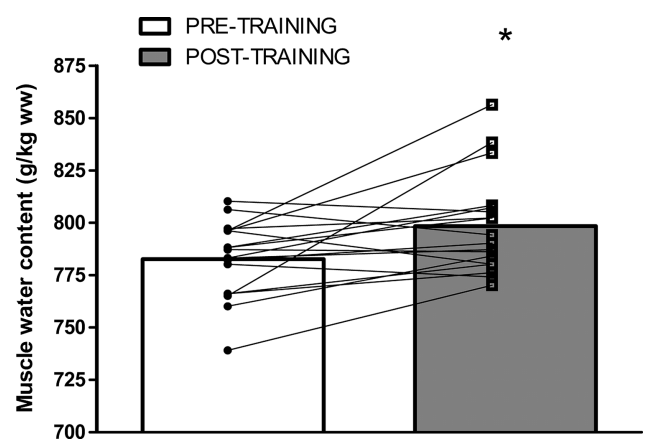

FIGURE 1-Changes in muscle water $\left(\mathrm{H}_{2} \mathrm{O}_{\text {muscle }}\right)$ before and after 4 months of AIT in metabolic syndrome patients. Data are presented as individual responses and means for 18 subjects. *Significantly different from pretraining values $(P<0.05)$.
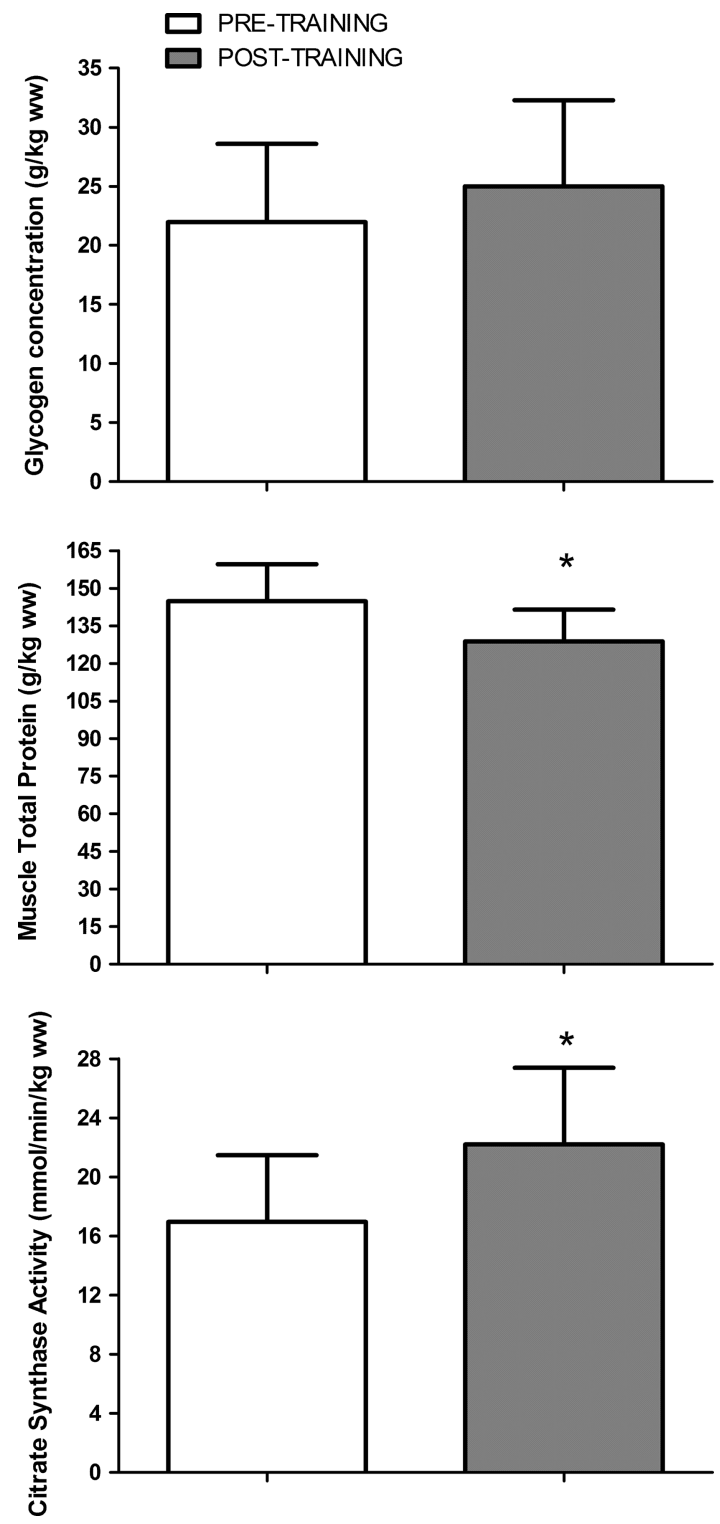

FIGURE 2-Changes in muscle glycogen, protein concentrations, and citrate synthase activity expressed as per kilogram of wet muscle (physiological conditions) before and after 4 months of AIT in metabolic syndrome patients. Data are means \pm SEM for 18 subjects. *Significantly different from pretraining values $(P<0.05)$.

composition improvements previously reported in the literature (21). Our subjects lost body weight and fat mass $(-1.9 \%$ and $-5.4 \%$, respectively; Table 1). They also increased their cardiorespiratory fitness, exercise maximal fat oxidation, and cycling peak power by $11 \%, 33 \%$, and $10 \%$, respectively (Table 1). The novel finding of our study is that skeletal muscle (i.e., vastus lateralis) water content (i.e., $\mathrm{H}_{2} \mathrm{O}_{\text {muscle }}$ )

TABLE 2. Correlation (Pearson $r$ ) between changes (i.e., $\Delta$ ) in muscle variables after 4 months of AIT.

\begin{tabular}{|c|c|c|c|c|}
\hline & $\Delta \mathrm{H}_{2} \mathrm{O}_{\mathrm{ms}}$ & $\Delta$ [Glycogen] & $\Delta[\text { Protein }]_{\mathrm{ms}}$ & $\Delta \mathrm{CS}_{\text {activity }}$ \\
\hline$\Delta \mathrm{H}_{2} \mathrm{O}_{\mathrm{ms}}$ & - & -0.659 & -0.687 & -0.759 \\
\hline$\Delta$ [Glycogen] & & - & 0.328 & 0.475 \\
\hline$\Delta[\text { Protein }]_{\mathrm{ms}}$ & & & - & 0.680 \\
\hline$\Delta \mathrm{CS}_{\text {activity }}$ & & & & - \\
\hline
\end{tabular}

The required coefficient of correlation for $n=18$ and $P \leq 0.05$ is 0.470 
increased, whereas, surprisingly, muscle total protein concentration decreased after 4 months of aerobic training.

DXA analysis reflected an increase in leg FFM suggestive of muscle hypertrophy despite reductions in muscle protein concentration. Other investigators have shown hypertrophic response to similar cycling endurance training programs in older women and men using microscopic determination of the myofiber diameter and magnetic resonance imaging of the leg $(12,14)$. Our data suggest that increases in muscle water content notably participates in the hypertrophic response to aerobic training in middle-age (54 \pm 8 yr old) initially untrained metabolic syndrome men. It also suggests that the mild hypertrophic response to aerobic training detected in our individuals is not due to muscle protein accretion. Furthermore, correlations (Table 2) suggest that the reduction in protein concentration is related to the gain in muscle water probably through a dilution effect.

It seems contradictory that aerobic training would reduce muscle protein concentration although improve leg muscle power (i.e., peak cycling power; Table 1). It could be argued that the weight loss experienced by our subjects set them in a catabolic state, preventing muscle protein anabolism or muscle protein accretion. However, our subjects neither followed a hypocaloric diet nor reduced the percent of protein ingested in the diet (i.e., $21 \%$ of energy intake). Thus, the moderate weight loss experienced during training (i.e., $1.85-\mathrm{kg}$ weight loss or $1.9 \%$ of body mass) was most likely induced by a lack of compensatory increase in calorie intake to match energy expenditure during training. In fact, most of the weight loss $(93 \%$; i.e., 1.73 out of $1.85 \mathrm{~kg})$ could be accounted for by reduction in fat mass tissue (Table 1) in the abdominal region as judged by the reduction in waist perimeter. Harber et al. (12) subjected old women $(71 \pm 2 \mathrm{yr}$ old) to $12 \mathrm{wk}$ of aerobic training and also found increased skeletal muscle water content and reductions in muscle protein concentration despite null losses of body weight. Furthermore, they measured isolated fiber contractile function and found increased unloaded contraction velocity and absolute power in type I fibers (12). Our data amount to theirs to suggest that aerobic training improves leg peak power $\left(W_{\max }\right.$; Table 1) despite reducing muscle protein concentration.

Although $\mathrm{H}_{2} \mathrm{O}_{\text {muscle }}$ gains have been reported as an acute response during the first stages of moderate (5) and intense exercise (30), we are the first to report an increased $\mathrm{H}_{2} \mathrm{O}_{\text {muscle }}$ $72 \mathrm{~h}$ after the final session of exercise of a 4-month-long training program. We interpret this to suggest that gain in muscle water is another of the adaptations to endurance training. Aerobic or resistance training seems to reduce specific force (the ratio between isometric force and fiber cross-sectional area) in both young $(18)$ and old subjects $(12,14)$. Reduction in specific force evidences that the increase in size due to aerobic training is not entirely functional. Others have suggested that the reduced specific force is due to edema or swelling. Increased in $\mathrm{H}_{2} \mathrm{O}_{\text {muscle }}$ diluting myofibrillar protein could explain the reduced specific force after aerobic training reported in the literature. Our measurements of increased $\mathrm{H}_{2} \mathrm{O}_{\text {muscle }}$ support this view.
The gain in muscle water that we observed may have remodeled vastus lateralis fibers' contractile performance. Dehydration of rat skinned isolated single fibers by bathing the muscle preparation in a hyperosmotic fluid $(10 \%$ dextran) reduces the space between myofilaments (myosin and actin) and lowers the maximal shortening velocity. The authors suggest that filament lattice compression likely affects the rate constant for cross-bridge detachment (19). In humans, $17 \mathrm{~d}$ of bed rest increased the type I fiber unloaded shortening velocity, although they reduced their peak isometric force (39). On the other hand, resistance training can increase the muscle strength and cross-sectional area without changes in myofilament spacing (3) when a reduction in this spacing was expected because of myofilament packing (27). It is then possible that the gain in muscle water reported presently constitutes a training adaptation geared to increase the space between thin and thick filaments allowing faster cross-bridge cycling. Vastus lateralis importantly contributes to cycling mechanics, and the increase in cycling power in our data suggests improvement in the rate of force applied to the pedals from this muscle. Based on the current literature, it is reasonable to hypothesize that the gains in muscle water content increased filament spacing allowing higher muscle power.

Our proxy marker of mitochondrial density (citrate synthase activity) increased by $31 \%$ with the completion of the 48 exercise training sessions (Fig. 2). Mitochondria constitutes approximately $4 \%-6 \%$ of muscle tissue (15), and its proliferation could be contributing to the modest leg hypertrophy currently reported (Table 1). However, the decrease in protein concentration is counterintuitive in the face of an increased mitochondrial density. Sarcomeres have more pro- AQ8 tein concentration than mitochondria and thus a superior mitochondrial proliferation with respect to sarcomere could explain the reduction in total protein concentration. We did not separate the different protein fractions, but Harber et al. (12) reported that $12 \mathrm{wk}$ of aerobic training reduces myofibrillar protein although does not affect sarcoplasmic protein concentration. Thus, the large increase in citrate synthase suggests gains in mitochondria that may have contributed to the reduced protein concentration.

On the other hand, the increased $\mathrm{H}_{2} \mathrm{O}_{\text {muscle }}$ with aerobic training may be influenced by the $14 \%$ higher muscle glycogen storage after training. The literature suggest that muscle glycogen may require water for its storage $(10,24)$. Other researchers have proposed that the combined increases in mitochondrial volume and glycogen stores could account for a significant portion of the increases in leg cross-sectional area with exercise training (23). Water and glycogen were the two components of muscle that increased after training. The increase in muscle water content was inversely associated with typically regarded adaptations to endurance training such as increased muscle glycogen, protein concentration, and citrate synthase activity (Table 2). This inverse association reveals the strong dilution effect that muscle water has in these muscle metabolites. In fact, the changes in glycogen, protein, and citrate synthase were 
positively associated among them, probably driven by the dilution effect of water in all of them.

In contrast, other investigators have reported no changes in $\mathrm{H}_{2} \mathrm{O}_{\text {muscle }}$ after training young individuals using resistance training (17). Competitive runners display lower muscle water content than recreational runners (29), arguing against muscle water expansion as an adaptation to endurance training. However, the same authors found that training for a marathon reduces slow and fast twitch fiber size (35). A deficit in nutritional water during the extraneous training for the marathon may refrain the otherwise natural muscle water expansion. Of note, our findings of increased $\mathrm{H}_{2} \mathrm{O}_{\text {muscle }}$ with training might be specific to very untrained individuals because our subjects' $\dot{\mathrm{V}} \mathrm{O}_{2 \text { peak }}$ ranked in the lower $20 \%$ percentile according to the American College of Sports Medicine guidelines (38). Possibly, the initial muscle atrophy due to detraining and a suboptimal muscle water content may set the scenario for the increases in muscle water content with aerobic training. In fact, muscle water content before training in the current metabolic syndrome men was $8 \%$ lower than in a group of young endurance-trained cyclist recently tested in our laboratory (363 \pm 9 vs $395 \mathrm{~mL}$ per 100 -g dw) (9). Likewise, initial muscle water levels may explain why identical training increased muscle water content in old women $(71.9 \% \pm 1.0 \%$ of water in muscle) (13) but not in old men ( $77.8 \% \pm 0.9 \%$ of water in muscle) (14). Our data suggest that muscle water expansion is not gender specific because our men increased muscle water content, but it is influenced by

\section{REFERENCES}

1. Alberti KG, Eckel RH, Grundy SM, et al. Harmonizing the metabolic syndrome: a joint interim statement of the International Diabetes Federation Task Force on Epidemiology and Prevention; National Heart, Lung, and Blood Institute; American Heart Association; World Heart Federation; International Atherosclerosis Society; and International Association for the Study of Obesity. Circulation. 2009;120(16):1640-5.

2. Broqvist M, Dahlström U, Karlsson E, Larsson J. Muscle water and electrolytes in severe chronic congestive heart failure before and after treatment with enalapril. Eur Heart J. 1992;13(2):243-50.

3. Claassen H, Gerber C, Hoppeler H, Lüthi JM, Vock P. Muscle filament spacing and short-term heavy-resistance exercise in humans. J Physiol. 1989;409:491-5.

4. Cohen J. Statistical Power Analysis for the Behavioural Sciences. In. Hillsdale (NJ): Lawrence Erlbaum Associates; 1988. p. 567.

5. Costill DL. Sweating: its composition and effects on body fluids. Ann N Y Acad Sci. 1977;301:160-74.

6. Costill DL, Coté R, Fink W. Muscle water and electrolytes following varied levels of dehydration in man. J Appl Physiol. 1976; 40(1):6-11.

7. Costill DL, Cote R, Fink WJ. Dietary potassium and heavy exercise: effects on muscle water and electrolytes. Am J Clin Nutr. 1982;36(2):266-75.

8. Costill DL, Coté R, Fink WJ, Van Handel P. Muscle water and electrolyte distribution during prolonged exercise. Int $J$ Sports Med. 1981;2(3):130-4.

9. Fernández-Elías VE, Hamouti N, Ortega JF, Mora-Rodriguez R. Hyperthermia, but not muscle water deficit, increases glycogen use during intense exercise. Scand J Med Sci Sports. 2015; 25(1 Suppl):126-34. pretraining water content $(73.8 \%$ of initial muscle water in muscle in our data).

In summary, we found increases in muscle water as a result of an endurance training program in much deconditioned $\left(\dot{\mathrm{VO}}_{2 \text { peak }} 28.8 \pm 7 \mathrm{mLO}_{2} \cdot \mathrm{kg}^{-1} \cdot \mathrm{min}^{-1}\right)$ obese metabolic syndrome men. The increases in muscle water were negatively associated with changes in protein and glycogen muscle concentration, suggesting a dilution effect. Nevertheless, glycogen concentration tended to increase while muscle protein concentration decreased. Interestingly, the increases in muscle water rather than protein accretion can explain the mild leg hypertrophy observed after the endurance training program (48 sessions). Two possible factors accounting for the increased cycling peak power despite reduced total muscle protein are improved neuromuscular function with training and/or myofilament remodeling linked to the gains in muscle water. Lastly, the diluting effect of muscle water expansion should be taken into account when expressing muscle metabolites or substrates as per unit of wet weight (i.e., original physiological state).

We thank the help and collaboration of Dr. Jacinto Alonso Azcarate from the Faculty of Environmental Sciences and Biochemistry at the University of Castilla-La Mancha. We also acknowledge the dedication of each of the participants in this study.

The study was partially funded with a grant from the Spanish Ministry of Economy and Competiveness (DEP2014-52930-R). The authors declare no conflicts of interest. The results of the present study do not constitute endorsement by the American College of Sports Medicine.

10. Fernández-Elías VE, Ortega JF, Nelson RK, Mora-Rodriguez R. Relationship between muscle water and glycogen recovery after prolonged exercise in the heat in humans. Eur J Appl Physiol. 2015; 115(9):1919-26.

11. Frayn KN. Calculation of substrate oxidation rates in vivo from gaseous exchange. J Appl Physiol. 1983;55(2):628-34.

12. Harber MP, Konopka AR, Douglass MD, et al. Aerobic exercise training improves whole muscle and single myofiber size and function in older women. Am J Physiol Regul Integr Comp Physiol. 2009; 297(5):R1452-9.

13. Harber MP, Konopka AR, Douglass MD, et al. Aerobic exercise AQ9 training improves whole muscle and single myofiber size and function in older women. Am J Physiol. 2009;297(5):R1452-9.

14. Harber MP, Konopka AR, Undem MK, et al. Aerobic exercise training induces skeletal muscle hypertrophy and age-dependent adaptations in myofiber function in young and older men. $J \mathrm{Appl}$ Physiol. 2012;113(9):1495-504.

15. Hoppeler H, Howald H, Conley K, et al. Endurance training in humans: aerobic capacity and structure of skeletal muscle. $J$ Appl Physiol. 1985;59(2):320-7.

16. Jenzano JW, Hogan SL, Noyes CM, Featherstone GL, Lundblad RL. Comparison of five techniques for the determination of protein content in mixed human saliva. Anal Biochem. 1986;159(2):370-6.

17. Lundberg TR, Fernandez-Gonzalo R, Gustafsson T, Tesch PA. Aerobic exercise does not compromise muscle hypertrophy response to short-term resistance training. $J$ Appl Physiol. 2013;114(1):81-9.

18. Lundberg TR, Fernandez-Gonzalo R, Tesch PA. Exercise-induced AMPK activation does not interfere with muscle hypertrophy in response to resistance training in men. $J$ Appl Physiol. 2014;116(6): 611-20. 
19. Metzger JM, Moss RL. Shortening velocity in skinned single muscle fibers. Influence of filament lattice spacing. Biophys $J .1987$; 52(1):127-31.

20. Mora-Rodríguez R, Fernández-Elías VE, Hamouti N, Ortega JF. Skeletal muscle water and electrolytes following prolonged dehydrating exercise. Scand J Med Sci Sports. 2015;25(3):e274-82.

21. Mora-Rodriguez R, Ortega JF, Hamouti N, et al. Time-course effects of aerobic interval training and detraining in patients with metabolic syndrome. Nutr Metab Cardiovasc Dis. 2014; 24(7):792-8.

22. Neufer PD, Sawka MN, Young AJ, Quigley MD, Latzka WA, Levine L. Hypohydration does not impair skeletal muscle glycogen resynthesis after exercise. J Appl Physiol. 1991;70(4):1490-4.

23. Nygren AT, Karlsson M, Norman B, Kaijser L. Effect of glycogen loading on skeletal muscle cross-sectional area and $\mathrm{T} 2$ relaxation time. Acta Physiol Scand. 2001;173(4):385-90.

24. Olsson KE, Saltin B. Variation in total body water with muscle glycogen changes in man. Acta Physiol Scand. 1970;80(1):11-8.

25. Pace N, Rathbun EN. The body water and chemically combined nitrogen content in relation to fat content. J Biol Chem. 1945; 158:685-91.

26. Passonneau JV, Lauderdale VR. A comparison of three methods of glycogen measurement in tissues. Anal Biochem. 1974;60(2): 405-12.

27. Penman KA. Human striated muscle ultrastructural changes accompanying increased strength without hypertrophy. Res Q. 1970; 41(3):418-24.

28. Pietrobelli A, Formica C, Wang Z, Heymsfield SB. Dual-energy X-ray absorptiometry body composition model: review of physical concepts. Am J Physiol. 1996;271(6 Pt 1):E941-51.
29. Reidy PT, Hinkley JM, Trappe TA, Trappe SW, Harber MP. Protein composition of endurance trained human skeletal muscle. Int J Sports Med. 2014;35(6):476-81.

30. Sjøgaard G, Saltin B. Extra- and intracellular water spaces in muscles of man at rest and with dynamic exercise. Am J Physiol. 1982; 243(3):R271-80.

31. Snyder WS, Cook MJ, Nasset ES, Karkhausen LR, Howells GP, Tipton HI. Report of the Task Group on Reference Man. Oxford (United Kingdom): Pergamon Press; 1975.

32. Srere PA. Citrate synthase. Methods Enzymol. 1969;13:3-11.

33. Tarnopolsky MA, Pearce E, Smith K, Lach B. Suction-modified Bergström muscle biopsy technique: experience with 13,500 procedures. Muscle Nerve. 2011;43:717-25.

34. Tjønna AE, Lee SJ, Rognmo Ø, et al. Aerobic interval training versus continuous moderate exercise as a treatment for the metabolic syndrome: a pilot study. Circulation. 2008;118(4):346-54.

35. Trappe S, Harber M, Creer A, et al. Single muscle fiber adaptations with marathon training. J Appl Physiol. 2006;101(3):721-7.

36. Wang Z, Deurenberg P, Wang W, Pietrobelli A, Baumgartner RN, Heymsfield SB. Hydration of fat-free body mass: review and critique of a classic body-composition constant. Am J Clin Nutr. 1999;69(5):833-41.

37. Wang ZM, Pierson RN Jr, Heymsfield SB. The five-level model: a new approach to organizing body-composition research. Am J Clin Nutr. 1992;56(1):19-28.

38. Whaley MH, Brubaker PH, Otto RM, Armstrong LE. ACSM AQ10 Guidelines for Exercise Testing and Prescription. American College of Sports Medicine; 2006. pp. 79-80.

39. Widrick JJ, Romatowski JG, Bain JL, et al. Effect of 17 days of bed rest on peak isometric force and unloaded shortening velocity of human soleus fibers. Am J Physiol. 1997;273(5 Pt 1):C1690-9. 


\section{AUTHOR QUERIES}

\section{AUTHOR PLEASE ANSWER ALL QUERIES}

AQ1 = Please confirm that given names and surnames have been identified correctly. $\mathrm{AQ} 2$ = Please check if the highest academic degree of the corresponding author is correct. AQ3 = Please provide the city and state/country of 3M.

AQ4 = Please spell out CV throughout the article.

AQ5 = Please provide the city and state/country of IBM.

AQ6 = In Table 2, should "ms" be changed to "muscle"?

$\mathrm{AQ7}=$ The sentence beginning "In fact, most of the" has been altered for clarity, please check that the meaning is correct.

AQ8 = The sentence beginning "Sarcomeres have more" has been altered for clarity, please check that the meaning is correct.

AQ9 = References 12 and 13 contain almost the same data. Please check and renumber.

$\mathrm{AQ10}=$ Ref. 38: Please provide the publisher location (city and state/country).

\section{END OF AUTHOR QUERIES}

